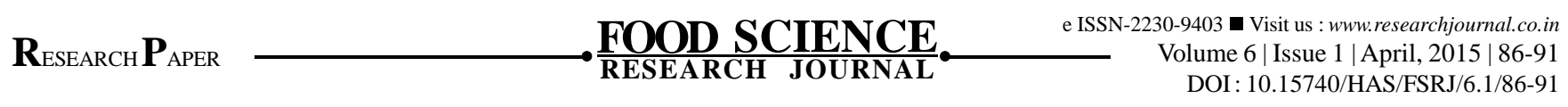

\title{
Utilization of finger millet flour in noodle
}

\author{
V. M. Londhe, S.S. Thorat and K.P. Babar
}

\begin{abstract}
Wheat and finger millet flour was prepared, analyzed for proximate composition and used in various combinations like 100:00, 90:10, 80:20, 70:30, 60:40 for the preparation of noodles. These noodles were evaluated for nutritional and sensory parameters. Noodles incorporated with finger millet flour showed inverse relation with protein and direct relation with other nutritional components such as carbohydrate, fat, crude fibre, ash, iron and calcium. Nutritional and sensory score parameters indicated that good quality noodles can be prepared by replacement of wheat flour with 30 per cent finger millet flour. This nutrient rich noodle will be good source of instant food for children, teenagers, sport persons, pregnant and lactating women.
\end{abstract}

Key Words : Finger millet, Noodle, Nutritious food

How to cite this article : Londhe, V.M., Thorat, S.S. and Babar, K.P. (2015). Utilization of finger millet flour in noodle. Food Sci. Res. J., 6(1): 86-91. 